\title{
Adequacy of Protein Intake among Korean Elderly: An Analysis of the 2013-2014 Korea National Health and Nutrition Examination Survey Data
}

\author{
Hyun Ah Park* \\ Department of Family Medicine, Inje University Seoul Paik Hospital, Inje University College of Medicine, Seoul, Korea
}

Background: Protein intake in South Korea is generally considered to be adequate; however, there is concern that it may be inadequate among the elderly. This study evaluated the adequacy of protein intake, the source of protein, and the distribution of protein intake in daily meals in the Korean elderly population.

Methods: Data were obtained from 1,484 men and 2,028 women aged 60 years or older who had participated in the nutrition survey of the 2013-2014 Korea National Health and Nutrition Examination Survey. One-day (24-hour) recall data were used to estimate the daily protein intake.

Results: The mean protein intake was $65.3 \pm 1.0 \mathrm{~g} / \mathrm{d}(13.1 \% \pm 0.1 \%$ of energy $)$ and $49.7 \pm 0.7 \mathrm{~g} / \mathrm{d}(12.6 \% \pm 0.1 \%$ of energy) for men and women, respectively. The protein intake was less than the estimated average requirement in $30.8 \% \pm 1.4 \%$ of men and $42.6 \% \pm 1.3 \%$ of women, and $47.9 \% \pm 1.6 \%$ and $60.1 \% \pm 1.4 \%$, respectively, consumed less than the recommended daily allowance. The protein intake was relatively evenly distributed among meals; however, the absolute amount of protein consumption per meal was very low. Only one-third of the protein intake came from animal sources.

Conclusion: The quantity and quality of protein intake were inadequate in the elderly Korean population.

Keywords: Aged; Protein; Animal Protein; Plant Protein

Received: December 21, 2016, Revised: February 16, 2017, Accepted: February 25, 2017

*Corresponding Author: Hyun Ah Park https://orcid.org/0000-0003-2343-8964

Tel: +82-2-2270-0097, Fax: +82-2-2267-2030, E-mail: drparkhyunah@gmail.com 


\section{INTRODUCTION}

Protein intake in South Korea is generally considered to be adequate; however, there is concern that it may be inadequate among the elderly due to (1) their lower energy intake, ${ }^{1)}(2)$ the relatively high cost of quality protein foods, ${ }^{2)}$ and (3) the traditional rice-based Korean dietary patterns. This study evaluated the adequacy of protein intake, the source of protein, and the distribution of protein intake among meals in the elderly Korean population.

\section{METHODS}

This study included all adults over 60 years of age who had participated in the nutrition survey (NS) of the 6th Korea National Health and Nutrition Survey (KNHANES) from 2013 to 2014. Detailed descriptions of the plan and operation of the survey are described on the KNHANES website (http://knhanes.cdc.go.kr/). One-day (24-hour) recall data were used to estimate the daily protein intake in the study population. The nonresponse rates of the 2013 and 2014 24-hour recall were $0.2 \%$, and $0.0 \%$, respectively. ${ }^{3)}$ People who reported consuming less than 500 or more than $5,000 \mathrm{kcal}$ were excluded from the analyses.
The protein intake was quantified as (1) protein intake in grams per day; (2) percentage of energy from protein, and (3) grams per kilogram of body weight. The data are presented as means, standard errors, and percentiles of the distribution.

The adequacy of protein intake was calculated using the standard 2015 Dietary Reference Intakes for Koreans from the Korea Nutrition Society, which recommends an estimated average requirement (EAR) for protein intake of $0.73 \mathrm{~g} / \mathrm{kg} / \mathrm{d}$ and a recommended daily allowance (RDA) of $0.91 \mathrm{~g} / \mathrm{kg} / \mathrm{d}{ }^{4}{ }^{4}$ The distribution of protein intake among meals and the top 10 food sources were reported according to sex.

Analyses were performed using PASW SPSS Statistics for Windows ver. 18.0 (SPSS Inc., Chicago, IL, USA) to incorporate sampling weight considering the multistage probability sampling design of the KNHANES and the nonresponse. The study protocol was approved by the Institutional Review Board of Seoul Paik Hospital (IRB approval no., IIT-2016-290) and informed consent was waived.

\section{RESULTS}

The analytic sample included 1,484 men and 2,028 women representing $8,627,131$ Korean elderly. The mean protein intakes were $65.3 \pm 1.0$

Table 1. Protein intake and the proportion of the Korean elderly population with intake below the estimated average requirement and the recommended daily allowance

\begin{tabular}{|c|c|c|c|c|c|c|c|}
\hline \multirow{2}{*}{ Variable } & \multirow{2}{*}{ Category } & \multirow{2}{*}{ Mean \pm standard deviation } & \multicolumn{5}{|c|}{ Percentile } \\
\hline & & & 5th & 25th & 50th & 75th & 95th \\
\hline \multicolumn{8}{|l|}{ Protein intake (g/d) } \\
\hline \multirow[t]{4}{*}{ Men } & $60 \mathrm{~s}$ & $70.4 \pm 1.5$ & 28 & 47 & 65 & 84 & 137 \\
\hline & $70 s$ & $61.4 \pm 1.4$ & 25 & 41 & 56 & 76 & 112 \\
\hline & $\geq 80$ s & $52.2 \pm 2.4$ & 21 & 34 & 45 & 60 & 95 \\
\hline & Total & $65.3 \pm 1.0$ & 26 & 43 & 60 & 81 & 124 \\
\hline \multirow[t]{4}{*}{ Women } & $60 s$ & $55.6 \pm 1.0$ & 23 & 37 & 51 & 68 & 107 \\
\hline & $70 s$ & $45.4 \pm 1.0$ & 18 & 30 & 41 & 55 & 92 \\
\hline & $\geq 80$ s & $39.5 \pm 1.5$ & 16 & 26 & 35 & 48 & 72 \\
\hline & Total & $49.7 \pm 0.7$ & 19 & 32 & 45 & 61 & 98 \\
\hline Combined sexes & & $56.5 \pm 0.7$ & 22 & 36 & 51 & 71 & 109 \\
\hline \multicolumn{8}{|c|}{ Protein intake (\% energy) } \\
\hline \multirow[t]{4}{*}{ Men } & $60 \mathrm{~s}$ & $13.3 \pm 0.2$ & 8.2 & 11.1 & 12.9 & 15.2 & 19.6 \\
\hline & $70 s$ & $13.0 \pm 0.2$ & 7.9 & 10.3 & 12.3 & 14.5 & 19.9 \\
\hline & $\geq 80$ s & $12.5 \pm 0.4$ & 8.3 & 10 & 11.6 & 13.7 & 19.3 \\
\hline & Total & $13.1 \pm 0.1$ & 8.1 & 10.7 & 12.5 & 14.9 & 19.7 \\
\hline \multirow[t]{4}{*}{ Women } & $60 s$ & $13.1 \pm 0.1$ & 8.6 & 10.8 & 12.6 & 14.8 & 18.7 \\
\hline & $70 \mathrm{~s}$ & $12.2 \pm 0.2$ & 8 & 9.9 & 11.6 & 13.9 & 18 \\
\hline & $\geq 80$ s & $12.3 \pm 0.4$ & 7.6 & 9.6 & 11.3 & 13.8 & 19.2 \\
\hline & Total & $12.6 \pm 0.1$ & 8.1 & 10.3 & 12.1 & 14.4 & 18.6 \\
\hline Combined sexes & & $12.8 \pm 0.1$ & 8.1 & 10.4 & 12.3 & 14.5 & 19 \\
\hline \multicolumn{8}{|c|}{ Protein intake $(\mathrm{g} / \mathrm{kg} / \mathrm{d})$} \\
\hline \multirow[t]{4}{*}{ Men } & $60 \mathrm{~s}$ & $1.09 \pm 0.02$ & 0.42 & 0.72 & 0.99 & 1.3 & 2.05 \\
\hline & $70 s$ & $0.99 \pm 0.02$ & 0.39 & 0.64 & 0.9 & 1.19 & 1.84 \\
\hline & $\geq 80$ s & $0.90 \pm 0.04$ & 0.37 & 0.58 & 0.77 & 1.07 & 1.76 \\
\hline & Total & $1.03 \pm 0.02$ & 0.41 & 0.67 & 0.94 & 1.26 & 1.97 \\
\hline \multirow[t]{4}{*}{ Women } & $60 \mathrm{~s}$ & $0.97 \pm 0.02$ & 0.41 & 0.64 & 0.89 & 1.21 & 1.83 \\
\hline & $70 s$ & $0.83 \pm 0.02$ & 0.33 & 0.54 & 0.74 & 1.02 & 1.6 \\
\hline & $\geq 80$ s & $0.79 \pm 0.03$ & 0.29 & 0.5 & 0.72 & 0.94 & 1.56 \\
\hline & Total & $0.90 \pm 0.01$ & 0.35 & 0.57 & 0.8 & 1.1 & 1.73 \\
\hline Combined sexes & & $0.95 \pm 0.01$ & 0.38 & 0.62 & 0.85 & 1.18 & 1.83 \\
\hline
\end{tabular}


$\mathrm{g} / \mathrm{d}$ and $49.7 \pm 0.7 \mathrm{~g} / \mathrm{d}$ for men and women, respectively. The mean percentages of energy from protein were $13.1 \% \pm 0.1 \%$ for men and $12.6 \% \pm 0.1 \%$ for women, which were compatible with the Korean acceptable macronutrient distribution range for protein of $7 \%-20 \% .{ }^{4}$ Nonetheless, even elderly in the 95th percentile did not exceed the upper limit of $20 \%$ in all age and sex groups (Table 1 ).

Protein consumption less than the EAR was reported in $30.8 \% \pm 1.4 \%$ of elderly Korean men and $42.6 \% \pm 1.3 \%$ of elderly Korean women, and $47.9 \% \pm 1.6 \%$, and $60.1 \% \pm 1.4 \%$, respectively, consumed less than the RDA. The proportion of the population with inadequate intake increased with age and was higher in women than in men across all age groups (Table 1, Figure 1).

The protein intake was evenly distributed among meals, at $26.4 \% \pm 0.4 \%, 30.3 \% \pm 0.4 \%, 31.3 \% \pm 0.4 \%$, and $11.9 \% \pm 0.3 \%$ for breakfast, lunch, dinner, and snacks. However, the absolute amounts of protein intake and animal protein intake per meal were very low (Table 2). Only one-third of the protein intake was derived from animal sources.

The top 10 food sources and their contributions to the daily protein intake are listed in Table 3. Grains $(19.7 \pm 0.2 \mathrm{~g} / \mathrm{d})$ was the top protein source, followed by meat $(9.3 \pm 0.4 \mathrm{~g} / \mathrm{d})$, fish and shellfish $(7.4 \pm 0.3 \mathrm{~g} / \mathrm{d})$, vegetables $(5.3 \pm 0.1 \mathrm{~g} / \mathrm{d})$, and beans and legumes $(4.7 \pm 0.1 \mathrm{~g} / \mathrm{d})$.

\section{DISCUSSION}

In this study, more than half of the elderly population in Korea consumed less protein than the Korean RDA of $0.91 \mathrm{~g} / \mathrm{kg} / \mathrm{d}$. Furthermore, they consumed predominantly plant-based protein, raising concerns regarding the adequacy of quantity and quality of the protein intake in this population.

Because the age-related loss of skeletal muscle leads to a greater risk
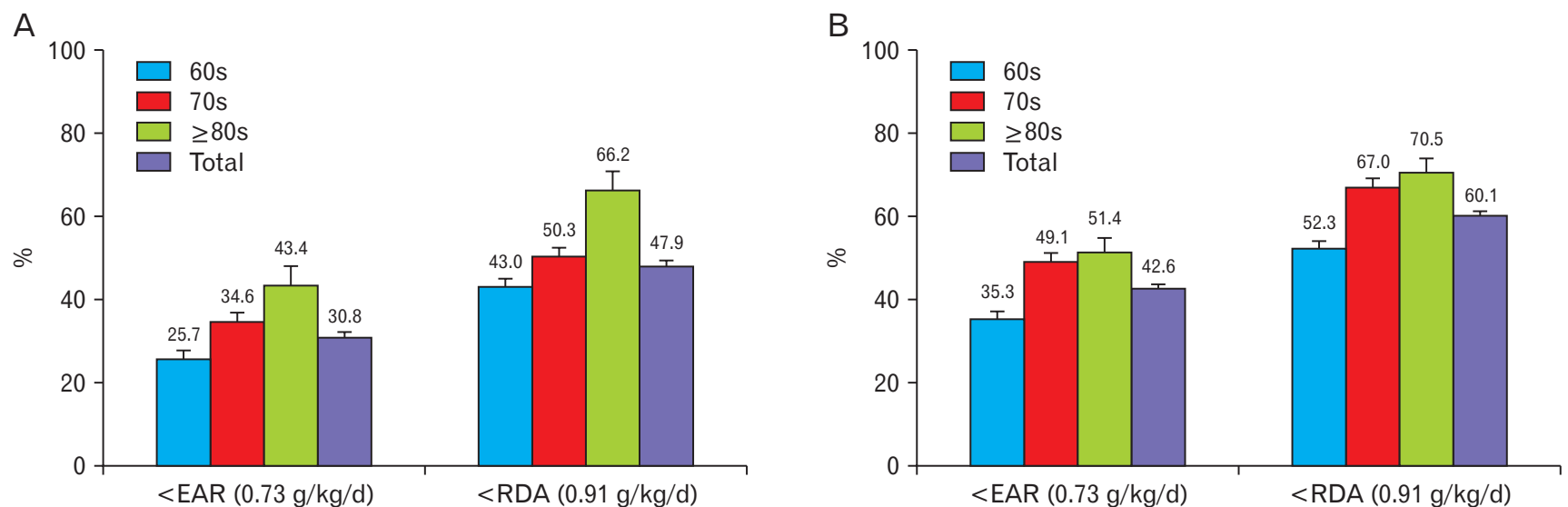

Figure 1. Proportion of the Korean elderly population with protein intake below the EAR and the RDA. The EAR and RDA were from the 2015 Dietary Reference Intakes for Koreans from the Korea Nutrition Society. (A) Men. (B) Women. EAR, estimated average requirement; RDA, recommended daily allowance.

Table 2. Distribution of protein intake among meals and snacks during a day in the Korean elderly population

\begin{tabular}{|c|c|c|c|c|}
\hline \multirow{2}{*}{ Variable } & \multicolumn{2}{|c|}{ Total protein intake } & \multicolumn{2}{|c|}{ Animal protein } \\
\hline & Mean \pm SE $(g / d)$ & Proportion \pm SE & Mean \pm SE $(g / d)$ & Proportion \pm SE \\
\hline \multicolumn{5}{|l|}{ Men } \\
\hline Breakfast & $16.7 \pm 0.3$ & $25.5 \pm 0.4$ & $5.3 \pm 0.2$ & $21.1 \pm 0.8$ \\
\hline Lunch & $20.0 \pm 0.6$ & $30.7 \pm 0.7$ & $8.1 \pm 0.5$ & $32.4 \pm 1.5$ \\
\hline Dinner & $21.3 \pm 0.5$ & $32.7 \pm 0.6$ & $9.3 \pm 0.4$ & $37.2 \pm 1.3$ \\
\hline Snacks & $7.3 \pm 0.3$ & $11.1 \pm 0.4$ & $2.3 \pm 0.2$ & $9.2 \pm 0.7$ \\
\hline Total & $65.3 \pm 1.0$ & 100.0 & $25.1 \pm 0.8$ & 100.0 \\
\hline \multicolumn{5}{|l|}{ Women } \\
\hline Breakfast & $13.6 \pm 0.3$ & $27.3 \pm 0.5$ & $4.0 \pm 0.2$ & $24.4 \pm 1.2$ \\
\hline Lunch & $14.9 \pm 0.3$ & $30.0 \pm 0.5$ & $5.0 \pm 0.2$ & $30.5 \pm 1.1$ \\
\hline Dinner & $14.9 \pm 0.4$ & $30.0 \pm 0.6$ & $5.4 \pm 0.3$ & $33.0 \pm 1.4$ \\
\hline Snacks & $6.3 \pm 0.2$ & $12.7 \pm 0.4$ & $2.0 \pm 0.1$ & $12.0 \pm 0.7$ \\
\hline Total & $49.7 \pm 0.7$ & 100.0 & $16.3 \pm 0.5$ & 100.0 \\
\hline \multicolumn{5}{|c|}{ Combined sexes } \\
\hline Breakfast & $14.9 \pm 0.3$ & $26.4 \pm 0.4$ & $4.6 \pm 0.2$ & $22.7 \pm 0.8$ \\
\hline Lunch & $17.1 \pm 0.3$ & $30.3 \pm 0.4$ & $6.3 \pm 0.3$ & $31.6 \pm 0.9$ \\
\hline Dinner & $17.7 \pm 0.3$ & $31.3 \pm 0.4$ & $7.1 \pm 0.3$ & $35.3 \pm 0.9$ \\
\hline Snacks & $6.7 \pm 0.2$ & $11.9 \pm 0.3$ & $2.1 \pm 0.1$ & $10.5 \pm 0.5$ \\
\hline Total & $56.5 \pm 0.7$ & 100.0 & $20.1 \pm 0.5$ & 100.0 \\
\hline
\end{tabular}


Table 3. Top 10 food groups and their contributions to daily protein intake in the Korean elderly population

\begin{tabular}{|c|c|c|c|}
\hline \multirow{2}{*}{ Rank } & \multicolumn{3}{|c|}{ Food group* (protein intake, g/d) } \\
\hline & Men & Women & Total \\
\hline 1 & Grains $(21.4 \pm 0.3)$ & Grains $(18.4 \pm 0.3)$ & Grains $(19.7 \pm 0.2)$ \\
\hline 2 & Meat $(12.2 \pm 0.7)$ & Meat $(7.0 \pm 0.4)$ & Meat $(9.3 \pm 0.4)$ \\
\hline 3 & Fish and shellfish $(9.4 \pm 0.5)$ & Fish and shellfish $(5.9 \pm 0.3)$ & Fish and shellfish $(7.4 \pm 0.3)$ \\
\hline 4 & Vegetables $(6.0 \pm 0.1)$ & Vegetables $(4.7 \pm 0.1)$ & Vegetables $(5.3 \pm 0.1)$ \\
\hline 5 & Beans and legumes $(5.2 \pm 0.2)$ & Beans and legumes $(4.3 \pm 0.2)$ & Beans and legumes $(4.7 \pm 0.1)$ \\
\hline 6 & Condiments $(2.6 \pm 0.1)$ & Condiments $(1.9 \pm 0.1)$ & Condiments $(2.2 \pm 0.1)$ \\
\hline 7 & Eggs $(1.9 \pm 0.1)$ & Dairy foods $(1.8 \pm 0.1)$ & Dairy foods $(1.7 \pm 0.1)$ \\
\hline 8 & Dairy foods $(1.5 \pm 0.1)$ & Eggs $(1.5 \pm 0.1)$ & Eggs $(1.7 \pm 0.1)$ \\
\hline 9 & Drinks and alcohols $(1.3 \pm 0.1)$ & Fruits $(1.2 \pm 0.1)$ & Fruits $(1.2 \pm 0.1)$ \\
\hline 10 & Fruits $(1.1 \pm 0.1)$ & Potatoes $(1.0 \pm 0.1)$ & Potatoes $(0.9 \pm 0.1)$ \\
\hline
\end{tabular}

Values are presented as mean \pm standard error.

*Based on the classification of the standards provided by the Korea National Health Statistics.

of functional impairment and mortality, the adequate intake of dietary protein is vital for maintaining muscle mass and function in the elderly. ${ }^{5)}$ Furthermore, the current RDAs based on nitrogen balance tests may not to adequately consider the protein requirement of the elderly with respect to their functionality. Experts in the field of protein and aging recommend a protein intake of at least $1.2-2.0 \mathrm{~g} / \mathrm{kg} / \mathrm{d}$ for elderly adults, ${ }^{6)}$ which is higher than current RDAs and considerably higher than the usual intake in the Korean elderly population.

In general, animal-based proteins are of a higher quality because they contain all of the essential amino acids that the human body requires, are more digestible, and are more likely to result in an adequate anabolic muscle response compared to that of plant-derived proteins. ${ }^{7-9)}$ Furthermore, higher animal protein intake contributes to higher odds of meeting the protein RDA because meat, poultry, and fish provide approximately twice the amount of protein while taking in fewer per mass equivalent of nuts or seeds. ${ }^{10)}$ However, grains were the largest protein-contributing food in the elderly in the present study. Only one-third of the protein intake was from animal sources, compared to two-thirds in American adults older than 51 years of age. ${ }^{10)}$

Western-style diets usually show skewed distributions of protein intake toward the evening meal because their main protein source is animal foods, which are typically served in the evening. ${ }^{10)}$ In contrast, the Korean elderly displayed a relatively even distribution of protein intake throughout the day, largely because the main protein source in the Korean elderly was grains, which were served at every meal. However, the protein intakes per meal per day were less than $20 \mathrm{~g}$, much lower than the recommended 25-30 $\mathrm{g}$ for the maximal stimulation of muscle, $^{8,11)}$ suggesting a persistent state of protein deficiency in the elderly.

The EAR and RDA of the elderly population are identical to those of young and middle-aged adults because the decreased bioavailability of protein intake in the elderly offset the decreased muscle mass. ${ }^{4}$ However, protein inadequacy exists only in the elderly population of Korea, as the mean protein intake of Korean young and middle-aged adults ranges from $74.9 \mathrm{~g} / \mathrm{d}$ to $86.1 \mathrm{~g} / \mathrm{d}$, far above their RDA ( $50 \mathrm{~g} / \mathrm{d}$ to $65 \mathrm{~g} / \mathrm{d}) .{ }^{12)}$ Further studies are needed to elucidate the discrepancy of protein intake among Korean adults by age group.
This study has several limitations. First, a single one-day (24-hour) recall might be too short to characterize the usual food intake patterns. Second, self-reported dietary data were used, which can under- and overestimate the actual intake. Third, although protein restriction is needed in case of severe kidney disease without renal replacement therapy and hepatic encephalopathy, ${ }^{7)}$ because we could not identify these people, they could have been included in our analysis. However, the NS of the KNHANES is currently the best available data to estimate dietary intake of the Korean elderly population.

The quantity and quality of protein intake are inadequate in the Korean elderly. To our knowledge, this is the first study to assess the adequacy of protein intake in terms of the intake and meal distribution and to provide baseline data on the nutritional state of elderly in Korea. This study may guide effective public health interventions to ensure adequate nutrition in the elderly.

\section{CONFLICT OF INTEREST}

No potential conflict of interest relevant to this article was reported.

\section{ACKNOWLEDGMENTS}

This work was supported by a National Research Foundation of Korea Grant from the Korean Government (NRF-2014S1A5B8044097).

\section{REFERENCES}

1. Millward DJ. Sufficient protein for our elders? Am J Clin Nutr 2008;88:1187-8.

2. Chernoff R. Protein and older adults. J Am Coll Nutr 2004;23(6 Suppl):627S-630S.

3. Ministry of Health and Welfare, Centers for Disease Control and Prevention. Korea health statistics 2014: Korea National Health and Nutrition Examination Survey (KNHANES VI-2). Sejong: Ministry of Health and Welfare; 2015.

4. Ministry of Health and Welfare, Korea Nutrition Society. Dietary refer- 
ence intakes for Koreans 2015. Sejong: Ministry of Health and Welfare; 2015.

5. Wolfe RR. The role of dietary protein in optimizing muscle mass, function and health outcomes in older individuals. Br J Nutr 2012;108 Suppl 2:S88-93.

6. Baum JI, Kim IY, Wolfe RR. Protein consumption and the elderly: what is the optimal level of intake? Nutrients 2016;8:E359.

7. Bauer J, Biolo G, Cederholm T, Cesari M, Cruz-Jentoft AJ, Morley JE, et al. Evidence-based recommendations for optimal dietary protein intake in older people: a position paper from the PROT-AGE Study Group. J Am Med Dir Assoc 2013;14:542-59.

8. Nowson C, O'Connell S. Protein requirements and recommendations for older people: a review. Nutrients 2015;7:6874-99.
9. Landi F, Calvani R, Tosato M, Martone AM, Ortolani E, Savera G, et al. Protein intake and muscle health in old age: from biological plausibility to clinical evidence. Nutrients 2016;8:E295.

10. Berner LA, Becker G, Wise M, Doi J. Characterization of dietary protein among older adults in the United States: amount, animal sources, and meal patterns. J Acad Nutr Diet 2013;113:809-15.

11. Paddon-Jones D, Rasmussen BB. Dietary protein recommendations and the prevention of sarcopenia. Curr Opin Clin Nutr Metab Care 2009;12:86-90.

12. Ministry of Health and Welfare, Centers for Disease Control and Prevention. Korea health statistics 2015: Korea National Health and Nutrition Examination Survey (KNHANES VI-3). Sejong: Ministry of Health and Welfare; 2016. 